\title{
THE IMPLEMENTATION OF RELIGIOUS CULTURE FOR PRATHOM LEVEL IN BAKONG PITTAYA SCHOOL PATTANI, THAILAND
}

\author{
Isna Imroatuz Zakiyati \\ isnaizakiya10@gmail.com \\ UIN Sunan Kalijaga Yogyakarta
}

\begin{abstract}
The aim of this research is to describe the implementation of religious culture in the prathom (elementary) level in Bakong Pittaya School Pattani, Thailand. The type of the research is field research. The data collecting method used in this study are observation, interview, and documentation. From the result of research, the writer found that the implementation of reaching religious culture is using the instructive sequential strategy through creating the religious atmosphere, values internalization, good example, habituation, and civilizing religious culture. Meanwhile, in civilizing religious culture, this school uses the power strategy with the reward-punishment approach and persuasive strategy with the habituation and exemplary approach. Moreover, there are 14 religious culture forms in the prathom level of Bakong Pittaya School, Pattani, Thailand.
\end{abstract}

Keywords: implementation; pattani; religious culture

\section{INTRODUCTION}

Thailand, officially the Kingdom of Thailand, formerly known as Siam, is a country at the centre of the Indochinese peninsula in Southeast Asia. With a total area of approximately $513,000 \mathrm{~km} 2(198,000 \mathrm{sq} \mathrm{mi})$, Thailand is the world's 51st-largest country. It is the 20th-most-populous country in the world, with around 66 million people. The prevalent religion in this country is Theravada Buddhism, which is an integral part of Thai identity and culture. Active participation in Buddhism is among the highest in the world. According to the 2000 census, $94.6 \%$ of the country's population self-identified as Buddhists of the Theravada tradition. Muslims constitute the second largest religious group in Thailand, comprising $4.6 \%$ of the population. Christians represent $0.9 \%$ of the population, with the remaining population consisting of Sikhs and Hindus, who live mostly in the country's cities. There is also a small but historically significant Jewish community in Thailand dating back to the 17th century (Wikipedia).

Islam is concentrated mostly in the country's southernmost provinces: Pattani, Yala, Satun, Narathiwat, and part of Songkhla Chumphon, which are predominantly Malay, most of whom are Sunni Muslims. Most of the places around the world minorities are generally under control of oppressive majoritarian rule, such as Malay Muslims in Southern Thailand. Most of the cases representatives of majoritarians are 
also getting a chance to achieve the controlling power of a nation through politics, education, or other way (Sarkar, 2014).

In Southeast Asia especially in Thailand, religious identity is often linked to ethnicity: Malays are Muslim; Thais are Buddhist; and Chinese are either Christian or syncretic Taoist/Buddhist. Although ethno-religious constructs shape identities, it can be said that in Thailand, Muslims and Buddhists share nearly identical social manners, perspectives, formalities and practices. They share the Southeast Asian social demeanour and conventions of moderation, compromise and mutual consultation. (Yusuf, 1999).

Further, the Muslim society in the southern Thailand have to maintain their Islamic identity and religion in the middle of Buddhist authority and society. Religion is a universal necessary and natural for humans. Humans need religion. Henri Bergson said that religion can not be separated from humans' life because religion is essential that accompanies humans in their life. Religious sense will emerge as the instinct of life (Alim, 2008). The citizen in the southern Thailand provinces hold the Islamic teachings tightly. Thai Muslims maintain, express and symbolize their identity through some ways, like the religious institutions such as the mosque, pondok or Madrasah and the office of the Chularatchamontri/Shaikh al-Islam, as well as through Islamic festivals celebrated at the national level, including Maulid al-Nabi (Yusuf, 1999). Moreover, nasyid music, a kind of music contains the religious values is really popular there.

Thus, madrasah become the important thing in establishing and maintaining religious sense and identity upon the students. It can be the place to engraft religious teachings. Schools are able to influence the growth of religion sense, morals, and other aspects through the learning process in the classroom and/or guidance outside the classroom. Schools have the functions to give abilities for children to be able to cultivate the values of religion in their life (Tafsir, 1996). Children from early days of schooling should be made aware of, and accustomed to, seeing differences of religious faiths and practices. The earlier the awareness is established, the better. The most important of religious education in schools is the practice of religions (Alwasilah, 2014).

The practice of religions and culture are engaged each other. Religious practice will interact with culture. So, culture is very important in the formation of a religious 
practice for a person or society (Khadziq, 2009). The religious culture that is applied in schools has goals to be achieved, one of which is to instill noble character in students (Majid \& Andayani, 2012). There are several strategies that can be done by education practitioners to shape the religious culture of the school as Ahmad Tafsir said, among others: 1) Give examples (examples); 2) Familiarize good things; 3) Enforce discipline, 4) Provide motivation and encouragement; 5) Give gifts especially psychological; 6) Punish (maybe in the framework of discipline), 7) Creation of religious atmosphere that influences the growth of children (Tafsir, 2004).

Bakong Pittaya School tried to internalize religious values and maintain Islamic identity through the religious culture. Religious culture is the religious atmosphere, such as prayer congregation, reading Al Qur'an, fasting, and others, which has been the habit and embedded in the daily life of the school's citizen. There are some activities in Bakong Pittaya School in order to implement religious culture, such as midday prayer congregation, qiroati, morning and afternoon ceremony, the commemoration of momentous days of Islam, and many more.

The religious culture in prathom level of Bakong Pittaya School emphasize in internalizing faith values. According to Suhainee $\mathrm{Abu}$, a prathom teacher, in some religious activities, the school tried to internalize and maintain it because they live in the middle of Budhist people and authority, so, their faith have to be strong and uneasy to be shaken. The Islamic identity was also established in this school, because they are the society of religion minority and they have to defend their identity as Muslims.

According to (Fathurrohman, 2015), religious culture is not only about the religious atmosphere, such as prayer congregation, reading Al Qur'an, fasting, and others, but religious culture is the religious atmosphere which has been the habit and embedded in the daily life and it needs the commitment from the stakeholders, among the principals, teachers, students or the officials.

There are also some researches that have ever done related to religious culture in the school, such as: research of (Winasih, 2013), the result showed that there were positive school culture and negative school culture. Most of the student was doing the positive school culture according to questionnaires data. The role of positive school culture could increase students achievement, this achievement was not only about good mark but also the student's behavior. 
Research of (Hasanah, 2014), The research showed there were some ways to optimize the learning strategy by internalization method, educate by giving good examples, bits of advice, supervision, punish and reward. The integration of Islamic values in the learning process will grow the good habit and religious sense of students, such as greetings and respect to the teachers, worship diligently, the commemoration of momentous days of Islam and give alms every Friday.

Moreover, research of (Mulatsih, 2013), The results showed the religious culture were implemented in that school such as read Qur'an together, Friday religious event, TPA (Al Qur'an Lesson) on Friday evening, habituation of Dhuha and Dzuhur prayer, social service, habituation of $3 \mathrm{~S}$ (smile, greetings, and respect), pilgrimage guide, honesty canteen, commemoration of momentous days of Islam, Ramadhan boarding school, and shake hands every morning. Those religious cultures were supporting in understanding the Islamic education lesson.

Research of (Rahmahwati, 2015), The result of this research is about Islamic Education Lesson needed religious culture to apply the learning process, such as pray before and after the learning process, Dzuhur congregation, read Surah Yasin on Friday morning, woman's affair, the commemoration of momentous days of Islam, and give alms.

Based on the explanation and previous research above, the implementation of religious culture become the important thing to be done. To know more about the effort of this school in implementing the religious culture, so researcher interested in researching about "The Implementation of Religious Culture for Prathom Level in Bakong Pittaya School Pattani, Thailand".

\section{THE RESEARCH METHODS}

This type of research is field research where the researcher involved into the field or research's location to get the datas. In a field study, according to (Rugg \& Petre, 2007), the researcher was studying something, but that study doesn't necessarily mean intervening in any way. It belongs to the qualitative descriptive approach. It was done to explore and understand the meaning individuals or groups ascribe to a social or human problem. The process of research involves emerging questions and procedures, data typically collected in the participant's setting, data analysis inductively building from 
particulars to general themes, and the researcher making interpretations of the meaning of the data. The final written report has a flexible structure. Those who engage in this form of inquiry support a way of looking at research that honors an inductive style, a focus on individual meaning, and the importance of rendering the complexity of a situation (Creswell, 2010).

This research took place in Bakong Pittaya School Pattani, Thailand. This school is located at 65 M, 2 T. Bangkhau, Nongchik district, Pattani province, South Thailand 94170. The writer took this school as the research location because it was the location where the researcher did the internship and community service program for about five months. Moreover, Bakong Pittaya School is popular enough in Pattani province. This school has three level of education, i.e: Anuban (pre-school education), Prathom (elementary education), and Matthayom (high school education). This research focused on the prathom level education. Further, it has already done in March 2016.

Data collecting technique in this research used observation, interview, and documentation. It is a systematic and standardized procedure to obtain the desired data. In this research, the researcher used participative observation that involved into the research location and joined in activities there. This technique was choosen because it was flexible and intimate. In practice, the researcher used observation guideliness to observe events or matters contained in the research. Sometimes the researcher participated in the religious activities. The interview method was conducted directly. The research was done to dig deeper and know more abou the implementation of religious culture for prathom level in Bakong Pittaya School Pattani, Thailand. Moreover, the obtained documentation in this research were the brief history of the school establishment, the condition of teachers, students, and officials, the school organization, some pictures which had correlation with the research, and the others school's archives.

Data analysis method used in this research is analysis technique by Miles and Huberman, such as: data reduction, data display, and conclusion drawing. In this research, after researcher got the data which was very complex, the researcher selected and sorted the datas which was important and related to the research focus, namely the implementation of religious culture for prathom level in Bakong Pittaya School Pattani, Thailand. Data that had no correlation with the research should be separated from 
important data, but it must be saved in order to use when the researcher need it. However, if the data was really unused then it should be discarded.

Once the data is reduced, then the next step is to present the data. In qualitative research, data testing can be done in the form of a short description, chart, or the narrative text. In the qualitative research, the presentation of data could be done in the form of brief description, chart, correlation among categories, flowchart or the kind of it. The most commonly used is narrative text (Sugiyono, 2016). Through compiling data, so the data related to this research was organized, arranged in the connection pattern, so it will be easier to understand and able to plan further work based on what had been understood that. In this research, the data was presented in the form of the implementation of religious culture.

The last step in the data analysis activities was taking conclusion verification. The first conclusion was still temporary and could be changed if there were no evidence supported the conclusion itself, but, when the conclusion that was expressed in the early step was supported by valid and consistent evidences when researcher returned to the field to collect data, the conclusions were credible ones. Thus, the conclusion in qualitative research may be able to answer the problem formulation, but maybe not, because of problem in qualitative research is temporary and will be developed after research in the field (Sugiyono, 2016). The writer took a conclusion after reviewing all data and it was done to answer the problem of the research.

\section{THE RESULT OF THE RESEARCH AND THE DISCUSSION}

\section{Reaching Religious Culture in the School}

The positive school cultures do not just happen. They are built over time by those who work in and attend the school and by the leader who encourage and reinforce values and tradition. Educational sociologist Willard Waller argued that every school has a culture of its own, with a set of rituals and folkways and a moral code that shapes behavior and relationships. The religious activities in each schools might be different, it was because the characteristic of the schools was different, the characteristic of the students can influence too (K. D. Peterson \& Deal, 2009).

According to (Sahlan, 2010), in reaching religious culture in the school can be done through the power's policy, it also known as the instructive sequential strategy. Schematically, that strategy can be seen in the image below: 


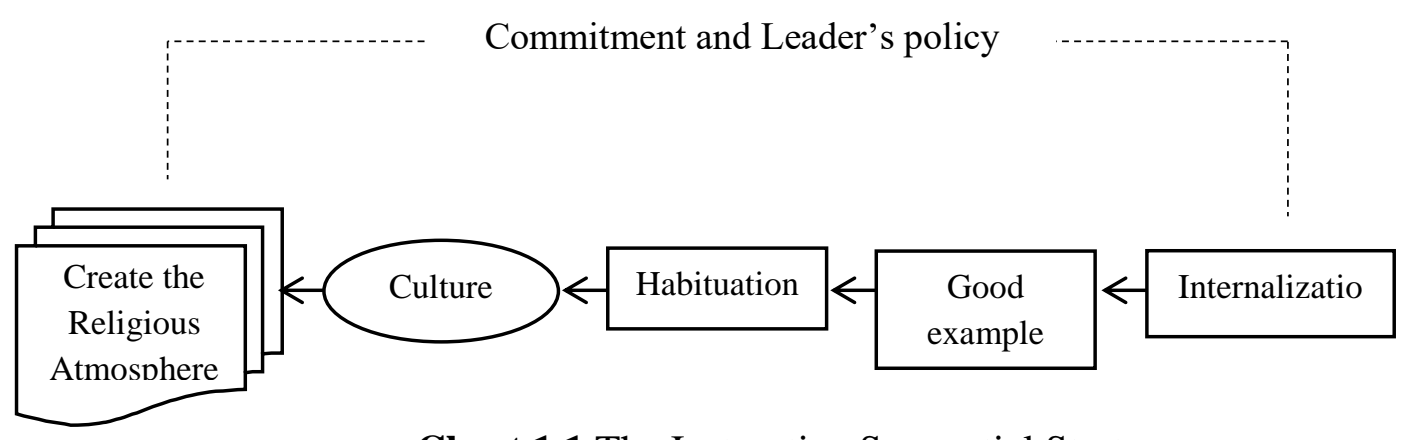

Chart 1.1 The Instructive Sequential Strategy

The picture above explains that the inception of the religious culture is more dominant in the structural aspects. This strategy relies on the commitment of school's leader through the policy set. The aims of this policy are realizing the religious culture through the process of creating a religious atmosphere, values internalization, good example, habituation and it will ultimately create the religious culture. However, this method has the weakness when the commitment of the leader and the control are no longer strong and consistent run in the school.

The prathom level of Bakong Pittaya School needed some efforts to reach religious culture, namely: creating religious atmosphere, values internalization, good example, habituation, and then it is become religious culture. In reaching religious culture, Bakong Pittaya School needed the stakeholder's power. The school created the religious atmosphere first, then the students would be internalized with religious values, the stakeholder also would give the good example, then the students would be habituated with the religious activities, so, it would become the religious culture.

There were religious atmosphere efforts were established by Bakong Pittaya School Pattani, Thailand, namely:

a. Daily Morning and Afternoon Ceremony

The daily morning and afternoon ceremony is held every day from Monday until Friday at 8.30 a.m before the learning activities and at 3.00 p.m before the students going home. All the prathom students gathered in the prathom hall. There was a teacher who had the duty on that day who will lead the students' guard in reading the prayer, the national anthem of Thailand, and continued with a short lecture. 
Meanwhile, the teacher would appoint one or three students to lead the students' guard in reciting the Divine Names (Asmaul Husna), the pillars of faith, and the pillars of Islam. The short lecture by the teacher in charge was able in any material, such as to keep the environment clean or the motivation to study hard, if there is an announcement about the school's holiday, it would also be announced in the morning or afternoon ceremony. If the season in Thailand at that time was the dry season with hot weather conditions, the school gave the policy to read the prayers in the classroom and led by each homeroom teacher. It was done to prevent the students from pain due to hot weather at that time. After the ceremony was over, the students lined up neatly to their class accompanied by the homeroom teacher.

b. Qiroati

Qiroati is held everyday from Monday to Friday before the learning process begin. The purpose of qiroati is to facilitate students in the learning of reading $\mathrm{Al}$ Qur'an outside the formal learning hours. Qiroati was held for about 30 minutes and guided by two teachers. The students alternately read the qiroati book for those who were still in qiroati level, and for those who were in Al Qur'an level would read the Koran. Meanwhile, the teachers wrote the description in the qiroati evaluation book of each student related to their reading.

With qiroati, the students will often practice in reading Al Qur'an because it is the Muslims holy book and must be learned and practiced in the daily life. If only rely on formal lesson hours in the classroom, maybe it will not enough to facilitate students in learning how to read it, so, qiroati is effective to maximize the students in learning to read Al Qur'an.

c. Commemoration of Momentous Days of Islam

These activities are held to memorize the historical days in Islam. In celebration of Muharram 10th, also known by Melayu people as Asyura Day, Bakong Pittaya School celebrated with making Asyura porridge and held the competition of MTQ (read Al Qur'an with the good tone) and Nasyid for prathom level. Since morning, the teachers, staff, and matthayom students had prepared in making Asyura porridge on a large skillet in the field next to the school. While waiting for the Asyura poridge was ready, in the school hall, there were the 
competition for prathom students and attended by the representatives from class 1 to 6. Finally, after the poridge was ready, the teachers divided the Asyura porridge to all prathom students to take home.

Ustadzah Masyitoh said that the month of Muharram is a worthy month and venerated by the ancient of Arab society. In the month of Muharram, there is a day named Asyura Day. Asyura word came from the Arabic language means ten. The Asyura Porridge is a tradition of Melayu society and still been preserved in Pattani. Ustadzah Masyitoh added, as Prophet Noah's ark anchored on Mount Judi, he ordered his followers to collect food items that still exist, the beans. Then, all the seven beans were cooked. It was the beginning of Asyura porridge.

While the prophet's birthday anniversary at that time was coincided with the Children Day in Thailand. This activity was enlivened by the appearance Nasyid and other performances from prathom and anuban students, and short lecture about the history of the Prophet Muhammad SAW, meanwhile, matthayom students were reading Maulid al Barzanji book.

d. Midday Prayer Congregation

The midday prayers congregation is an obligation for all students from class 1 to 6 after the lunch hour was over. Midday prayers congregation is held in two different places because the capacity of the school mosque is not enough to accommodate all students from grade one to six. Then, the students from class 1 to 3 do the midday prayer in the class which did not use anymore, while the class 4 to 6 do the midday prayer in the school mosque.

e. Friday Prayer congregation

Friday prayer congregation held every Friday by male students from class 4, 5 and 6 in the school mosque. Friday prayer was supervised by male teachers who participated in Friday prayer too. Meanwhile, the students in class 1, 2 and 3 have not been obligated to attend Friday prayers because they have not been baligh (mature term in Islam) and the capacity of school mosque was not too large, even some local residents also joined Friday prayers there.

For male students who did not pray, they will be stricken as the punishment. In Islam, the Friday prayer is an obligation for Muslim men. The school required for the students to perform Friday prayers to engraft the good habits and gives the 
understanding that Friday prayer is a prayer that must be done by men who are able to do.

f. Wear The Covered Uniform and Melayu Uniform

The majority of Pattani province's society is Moslem and they have unwavering principles in covering women's bodies. All women in Pattani certainly use the veil and it become the difference between Muslims and Non-Muslims there; if there is a woman who does not wear the veil then she can be assured that she is not a Muslim. This tradition and belief are supported by Bakong Pittaya School to require their students in wearing clothes which cover the aurat and syar' $i$.

The school provided uniforms for male students namely short-sleeved uniform and green trouser complete with a white cap. The uniform for the female students is long-sleeved white top and green colored skirt complete with a white veil. The uniforms were worn from Monday until Thursday. For Friday, the schools required uniforms with the typical model of Melayu ethnic, Melayu clothes for men and baju kurung for women.

g. Read Qur'an 1 Month before Examination

This activity was held one month before the final examination for class 6 . This activity was held at the qiroati's time in the class or in the school meeting room. The homeroom teacher of class 6 said that reading the Koran before the examination could be the medium to come closer to God and pray, and also could increase students' concentration. Anya Cheka, a student from class 6 said, when this activity began, the room or class will be very noisy with the student who read it loudly, but they were not disturbed and still able to concentrate on reading $\mathrm{Al}$ Qur'an. She was able to focus more even in the examination.

h. บำเพ็ญ ประโยชน์ = bam-pen bprà-yòht (useful activities)

Bam-pen means conduct, behave (merit or religious acts), and bprà-yòht means advantages, usefulness. In Bakong Pittaya School, this activity is held every Wednesday at 14.20 p.m until 15.00 p.m before the students going home. At that time, there will be no lesson and the students directed to do some service, such as cleaned the classroom, cleaned the school environment, or took the rubbish around the school. 


\section{i. Religion Quotes}

Religion quotes attached on the school wall. These religion quotes were taken from the hadith or scholars saying who have become proverbs. Based on observations by the researcher, the religion quotes in prathom level of Bakong Pittaya School are:

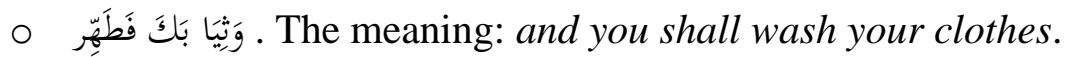

O قَدْ اَفْلَحَ مَنْ زَّاَهَا (9) وَقَدْ خَابَ مَنْ دَسَّاهَا (10) . Means: He is indeed successful who causeth it to grow (9) And he is indeed a failure who stunteth it (10). QS. As Syam 9-10.

O النظفة من الإيمان . The meaning: cleanliness is a part of faith.

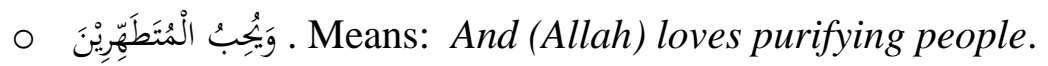

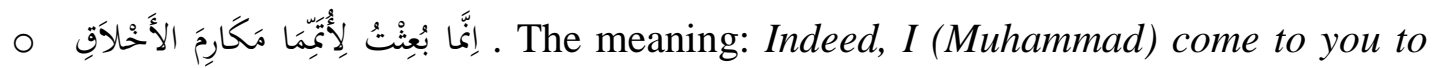
improve on morals.

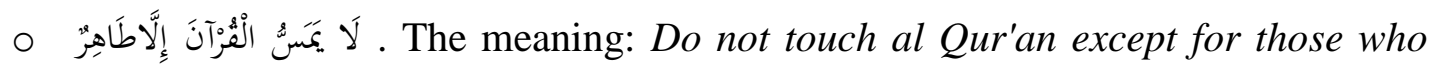
are pure of hadats. (Reported by Daruqutni and Baihaqi)

Religion quotes were attached on the walls of the school will be easy to read, because it was on the accessible place and could be seen easily by the students. The quotes were not the meaningless decoration, but it was expected to be internalized to the students and become the reference in daily life activities.

j. Extracurricular Activity (nasyid)

Nasyid has been the favorite kind of music for Pattani's citizen. In every event, there must be the nasyid performance. Based on the research, in prathom level of Bakong Pittaya School, the existed extracurricular activity is nasyid and the other extracurricular activities have not been projected yet. Prathom level has some nasyid group from each class that sometimes perform in school events, and also the nasyid group from choosen students that sometimes join the nasyid competition and another event too.

k. Khatm Al Qur'an (finish in reading the koran) for the 6th grade 
It is no doubt that reading the Koran is one form of worship that has a big reward. The primacy of the Koran is because it is Allah's word. The Qur'an is a holy book which was revealed with the full blessings. The Qur'an gives the direction to the human into the Straight Path.

After the final test was completed, as an expression of gratitude to God, the students from class 6 done the Khatm Al Qur'an and it coincided with the farewell party or gave the graduated license for all level students and attended by parents. Usman Toktayong, S.Pd said, by Khatm Al Qur'an, the school tried to improve the quality of graduates in grade 6 . The school convinced the quality of their graduates that indicated from the ability of the student in reading the Qur'an even finish it and it will be useful to the next step of student itself.

1. Give Ramadhan foods

When Ramadan month was coming, the school kitchen prepared the food for students According to Mrs. Tohiroh Salaeh, by giving the foods in holy month of Ramadhan, the students can learn about the superiority of giving foods in fasting month. So, when they have been baligh and have the obligation of fasting, they will do it with all their heart and can give some foods to others who need.

m. Festivity before the Examination

Come closer to the last semester exam, all the homeroom teachers and the students were so enthusiastic. They prepared the variety of necessary for the feast as an expression of gratitude for having passed one grade level and want to move up the higher class. This activity was an initiative of prathom teachers. The homeroom teachers and the students will contribute some money to buy the foods that will be eaten together in their classes. Even some of the students' parents sometimes volunteered to provide foods to be eaten together in that event. These foods such as lucin, salad, rice packs, songtam, etc. At the end of this agenda, they will pray together as the grateful expression and to be successful in doing the examination.

n. Forgive each other after the examination

After the examination over and the school holiday will come, the prathom teachers and the students gathered in the school hall and made the O-line, then, they 
apologized each other for all the mistakes they have made in one-year togetherness. It was ended by praying together for the success of all and come closer to God.

After the religious atmosphere in the school was created, then, the prathom level of Bakong Pittaya School tried to internalize the values in order to reach religious culture. Values internalization efforts which were found in prathom level of Bakong Pittaya School were done through the learning process or the religious atmosphere activities. Both of religion and general teacher try to internalize values through the learning process by giving the indoctrination, understanding, and the concrete example in the daily life by telling the story with full of values. It also could be integrated with the non-religion material by the general teachers.

Loewald uses internalization as a general term for the creation of inner experience through certain processes of transformation by relationships and interactions between the individual psychic apparatus and its environment are changed into inner relationships and interactions within the psychic apparatus'. Walrond-Skinner stated that internalization is a process whereby the individual transfers a relationship with an external object into his internal world'. Internalization is taken to encompass incorporation, introjection and identification mechanisms that create permanent internal mental representations out of objects and events (Ekwutosi \& Moses, 2013).

In Bakong Pittaya School, in the daily morning and afternoon ceremony, the internalization values was done through the short lecture by the teacher who have the duty in leading the students' guard. The teacher will give some advices and invitation to do the good deeds. Further, the students also habituated to be discipline by come to the prathom hall on time and back to their class neatly. Usman Toktayong, S.Pd said that the morning and afternoon ceremony was conducted in order to start something and finish it well. In this case, the learning process that began and ended with the prayers was expected to provide benefits and the students can understand well about the subject material, so the learning objectives can be achieved. In addition, through this activity was expected to engraft discipline upon students.

Furthermore, reading the pillars of Islam, the pillars of faith, and the Divine Names, have the aims to internalize the character of religious values contained in the Divine Name. The tauhid (faith) value also tried to internalize by reading the pillars of Islam and the pillars of faith with the intention to reinforce the faith into the students 
self. Thus, the students will be easier to be directed to the positive things. With the habituating and understanding of the Divine Names, the pillars of Islam and the pillars of faith, the students will be more familiar to God Almighty.

Moreover, in reading Al Qur'an, the school tried to internalize the faith values. It could be the medium to come closer to God and create the peaceful feeling. Further, in the commemoration of momentous days of Islam, stated by Ustadzah Masyitoh, the school tried to internalize the patriotism and heroism from the efforts of prophets. With this celebration, besides to remember the past struggles people, it also can continue in preserving the tradition of Melayu society. Furthermore, it was expected to get rewards from giving foods to others.

Meanwhile, in the prayer congregation, both of midday prayer and Friday prayer, the school tried to internalize the faith values. According to Mrs. Suhainee Abu, the habituation of midday prayer congregation was beneficial to make students done the worship at the beginning of time. Moreover, it was also intended as the tauhid foundation of the students in order to be the strong faith, because in their environment there were Buddhist people, so, they should be able to maintain their faith not to be easily shaken.

Further, in wearing the covered uniform and Melayu uniform, the schol tried to internalize the citizenship in the term of Melayu ethnic. According to Usman Toktayong, S.Pd, the school tried to preserve the culture of their Melayu ethnic. Thus, students will feel proud of their ethnic and students will not forget where they were from. The majority of three southern provinces of Thailand are Melayu ethnic and they were trying to defend their Melayu identity. One of the efforts is the application in using Melayu clothes at school. Furthermore, in wearing clothes which covered the aurat as well as the guardian of a negative act. The student who worn a cap or veil would be ashame if doing negative things.

Furthermore, in bam pen bpra yoht, the school tried to internalize the mutual help, keeping environment, and care for others. According to Mrs. Tohiroh Salaeh, from this activity, the students learned to be useful for others and gave what they can give even just the small thing. Every Muslim was commanded to provide benefits for others, and it will go back to them. The students also can learn how the important of the 
cleanliness in the school environment, because when the school is clean and good looking, we are comfort and enjoy the learning process.

Moreover, in religion quotes, the school expected to internalize what was contained in those quotes. In this case, the quotes in Bakong Pittaya School emphasized in keeping the environment and motivation to learn. Further, in the Nasyid extracurricular, the school tried to keep Pattani's culture. Most of nasyid songs contained the Islamic values and it was became the medium to internalize Islamic values itself, for example the faith value on the song from Mawaddah - Ingatlah Kematian, Akhdan - Tirai Malam, etc, and also the patriotism value on the song Perwira Melayu which was really popular there.

Furthermore, in the festivity before examination and forgiving each other after the examination, the teacher tried to internalize the grateful, graditude, and forgiving value. Ms. Nurisah Awebesar said that this activity is the initiative of prathom teachers as an expression of gratitude in the end of the class and immediately ready to move up to a higher level. In addition, these activities also as a little farewell party and the sweet memories with the homeroom teacher because the students would not be guided by the same homeroom teacher. Students also would learn the essence of forgiveness.

The elementary ages commonly still easy to be doctrinize because they are still in the heteronomous phase of ages like what is mentioned by J. Piaget and L. Kohlberg that the children are characterized by a compulsion, under pressure from adults or those in power, children use a little moral control and logic in their conduct and behavior. Further, they also like the stories which can be the medium to internalize the values. The teachers both of the general teacher and religion teacher have the role to internalize it. Sometimes, the teachers will just describe the good value while doctrinize the students, or through delivering the story which have the values on it, so the students can learn from it and the values will be internalized unconsciously.

The internalization of values upon the elementary students through doctrinization can establish the religious identity and awareness of them, it can be the base for the religion to be the good Muslims in their future. The sooner religious values is internalized, the better. The elementary school students from 6 years old started to think and emerge the concept of God in their mind. It is established based on their fantasy, for example God is like a human, God has large eyes, and so on. The school 
have the role to direct them in the good perception and understanding of God. Further, many adults obey in their religion law because of the influence of the religious teachings and practices conducted in childhood age. On the other hand, study about religion and internalizing values are harder in adulthood age.

For brevity's sake, there are some values which was internalized through the religious atmosphere, such as: faith, caring, discipline, forgiveness, gratitude, heroism and patriotism. The most internalized value in this school is the faith value. Faith value can be found in some religious activities, such as: the prayer congregation, qiroati and reading Al Qur'an, the daily ceremony, wearing the covered uniform and Nasyid activities with its songs. It is also can be found in other activities although not too dominant. Faith is the fundamental value which can be the base for the religious activities in the school and can be the base for moral improvement.

Ismail Raji Al Faruqi also mentioned about the important of faith value as the basic of education, because the faith value can be the base in thinking framework, doing, and acting in the daily life. Further, faith value can make someone always feels that Allah is watching him, so he will think more in doing the bad behavior and always try to run the God's commands.

Furthermore, in civilizing religious culture, the exemplary behavior from the stakeholder, teachers, and officials is also needed to give the good example for students. Researcher found exemplary behavior which was applied in prathom level of Bakong Pittaya School, such as: (a) wearing the covered uniform for all school citizen especially for the elder in order to give the good example for students, (b) discipline, the teachers came to the prathom hall on time when the morning ceremony would begin in order to make themselves as the good example for students, (c) respect each other, and (d) doing the good behave by all the stakeholder, teachers, and officials. Exemplary behavior is giving the good example to others in the good things.

Education with exemplary means the education by giving the sample, either in a direct, by hope it will be imitated by the learners. In the perspective of psychology, impersonation or identificationt something were a tendency or instinct (gharizah) that inherent in every human being, including figure imitating to anadmired figure. Associated with this term, (Al-Nahlawi, 1983) asserted that "In fact the need for exemplary figures sourced from imitating trend that has become a human character". 
In addition, (Ulwan, 1992) stated that exemplary behavior or giving the good example is effective enough to prepare and create the students moral, spiritual, and social. The educators and the school citizen are the ideal example in the students' view which will be followed by the students, conscious or not. It will embedded in the students' self in the form of the saying, doing, or acting. Although the students are potentially to reach the good behavior and receive good education, it will not be happened if their environment are not supported.

Reaching religious culture in this phase is effective enough to prepare and create the students moral, spiritual, and social. The educators and the school citizen are the ideal example in the students' view which will be followed by the students, conscious or not. It will embedded in the students' self in the form of the saying, doing, or acting.

The students from elementary level approximately are about six years old to eleven years old. At the ages, students still imitative and learn from what they have seen. Their religious concept influenced by the outside factors too. Children's religious characteristic is imitative even the children are the best imitator. So the school with all aspect on it have to give the good example for the students.

Moreover, the environment become the important thing in establishing the religious values. The school have to create the good environment with fully religiosity and Islamic identity on it. The religious atmosphere that established in the school can be the way to emerge the religious sense, identity, and awareness upon the students. That is why, the good example can not be separated in educating children and realizing religious culture.

The, the next is habituation. The researcher found the habituation efforts in reaching religious culture in almost all of the religious atmosphere or activities. The religious atmosphere which has been formed need the habituation to make it embedded in the students' self.

In addition, Mr. Usman Toktayong, S.Pd said that the habituation was important to be done and necessary because the students were still imitative. Every morning, the students were habituated to be discipline and pray the good readings. They also habituated to pray on time and do it with congregation. Further, the students were habituated to read Al Qur'an, wear the covered clothes, clean the school environment, grateful and gratitude, care for others, and forgive each others. By the habituation in 
doing the good culture, day by day, they will be better and accustomed to do this good habit in their daily life.

In addition, the school needs the habituation to habituate students to do the good things through the habituation of the religious activities. Bakong Pittaya School tried to habituate the good things to establish and maintain the good character and values upon the students.

Every morning, the students were habituated to be discipline and pray the good readings. They also habituated to do the worship on time and by the congregation. Further, the students were habituated to read Al Qur'an, wearing the covered clothes, clean the school environment, grateful, and forgive each others. Habituation was done because the students especially in the elementary ages are still need the direction what is good or bad. By the habituation in doing the good culture, day by day, they will be better and accustomed to do this good habit in their daily life.

Cultivating dispositions and instilling moral principles by habit and practice is not foreign to education, of course. It is a very old practice, one rooted from antiquity at the very heart of education itself. Aristotle advocated a kind of personality sculpting and conduct formation in the Nicomachean Ethics: "Virtue of character results from habit. A state of character arises from the repetition of similar activities." There are religious grounds for cultivating habits, as well (R. Peterson \& Wood., 2015). Abu Hamid Ghazali as one of the most influential scholars in the world of Islam. Ghazali equates moral education with habituation. Causality holds a prominent place in philosophical foundations of his theory of moral education (Attaran, 2015).

A state of character arises from the repetition of similar activities. Bakong Pittaya School, in order to reach the goals of religious culture, needs the habituation by practicing and doing the activities that develop the religious sense and awareness. They also have to do it regularly and constantly even there is also punishment if they were violated. Further, the stakeholder from the principals, teachers, and officials were also have the supervision and authorization of a noble educator.

(Attaran, 2015) stated that habituation in the Aristotelian ethics that has three main characteristics: (1) practicing the virtues by doing actions that develop moral excellences; (2) doing those actions regularly and constantly; (3) doing so under supervision and authorization of a noble educator. Further, (Attaran, 2015) argued there 
is no necessary connection between habitual moral actions and their implications, and one can have no certain hope that people could be trained through habituation; consequently, there should be a sufficient factor to guarantee moral education. This argument is tied with the belief in Allah, who determines the destiny of everything.

By the habituation especially in religion aspect, it can create the awareness in religion. If we have been habituated to read Al Qur'an, for example, we feel that there is something less if we did not read it in a day. The habituation in religion aspect is able to come closer to God, because we always represent God Almighty in our daily life.

Finally, religious culture will be reached with the efforts above named the instructive sequential strategy. This theory mentioned about the process and efforts in reaching religious culture, namely: (a) creating religious atmosphere, (b) values internalization, (c) good example, (d) habituation, and (e) religious culture will be reached. Those efforts needs the leader's policy and the commitment of the school's citizen in order to make it run well.

Religious culture in Bakong Pittaya School also needs the supports and commitment from the stakehoder, teachers, and officials to run it well. Teachers will supervise the students in doing some religious activities, as well as the officials in charge. Further, religious culture which has been reached still needs the efforts to make it always be embedded, civilized and maintained in the school citizen's self.

\section{Civilizing Religious Culture}

As mentioned above that the religious culture that has been realized needs the efforts to civilizing and maintain it. Moreover, (Muhaimin, 2006) stated the strategy to cultivate and maintain religious culture in schools can be done through:

a. Power strategy, the strategy of civilizing religion in the schools through the people's power, in this case the role of the principal in all its power is dominant in making changes.

b. Persuasive strategy, run through the opinions and views formation in their community or school.

c. Normative re-educative. Norms are rules in the community. Norm is civilized through education. It was run to instill and change the of citizens paradigm from the old paradigm with the new one. 
The strategy which is applied by prathom level of Bakong Pittaya School, are: the power stategy with reward-punishment approach and the persuasive strategy with the habituation and exemplary approach. The third strategy from Muhaimin named normative re-educatie was not applied in this school related to the characteristic of the elementary students ages that need more the supported environment, imitation, and people's power in running the religious culture.

According to (K. D. Peterson \& Deal, 2009), the school principals have power to organize the school culture besides teachers and officials. School principals take on many different roles. They are managers, working to keep their school's culture, structure and activities, policies and procedures, resources and programs, and rule and standards.

In addition, reward and punishment approach due to the power strategy give to the students as the motivation. Reward is used as the motivation for the good result or achievement by obeying the school rules. The reward could be the praise, a sincere smile, clapping the hands, or something which makes students feel good. Meanwhile, the punishment will make students become more wary. It is an effort to give the bad treatment in order to make them will not do that anymore (Arikunto, 2002).

Furthermore, in the second and third strategies were developed through habituation, exemplary and persuasive approach or invite the school citizens by giving reasons and good prospects that could convince them (Sahlan, 2010). Further, persuasive strategy through the habituation, exemplary and persuasive approach has the aims to change or influence the beliefs, attitudes, and behavior to act in accordance with what is expected.

In civilizing religious culture, prathom level of Bakong Pittaya School also needed some efforts. This school use the people's power with reward-punishment approach to maintain the religious culture, as well as the habituation and exemplary behavior approach which was done over and over. Mrs. Suhainee Abu said that the punishment is needed to be done to make the students want to do what they have to do. The punishment which was applied in this school was dominant through the physical punishment, such as by stricken with rattan or pinched. It was because they still imitate what Prophet Muhammad SAW said in hadith about the way to punish the children if they did want to pray. Meanwhile, the reward for the students was the praise. 
In addition, Usman Toktayong, S.Pd said that besides stricken or pinched, the students who did the violation over and over would be written down and report to the parents. The parents have to know what their children done, because from the morning until afternoon the students were under the school supervision.

The reward and punishment approach need the people's power. The stakeholder and the teachers have the power to regulate the students. In daily ceremony, the students were obligated to come to prathom hall. If there was still student who stayed in the class they would be threatened even punished with stricken or pinched by the officials who had the duty to check them. Meanwhile, in midday and Friday prayer congregation, there were some students who still did not want to pray, so, the homeroom teacher would supervise them. Students in violation would be stricken with rattan in their foot. If the student did not want to pray for many times, his or her name would be written down and report to the parents.

As well as the activities above, the students who are not obey in doing qiroati, Khatm Al Qur'an, read Al Qur'an one month before examination, and wearing covered uniform and Melayu uniform would be punished with the physical punishment still. For those who were obey with this obligation, the teachers sometimes would praise them.

Furthermore, besides reward and punishment approach, in civilizing religious culture, the prathom level of Bakong Pittaya School also still need the habituation, good example, and persuasive approach over and over. Moreover, the elementary school ages were still imitative and needed the elder's direction. So, those approach in civilizing religious culture was important to be done. In this good habituation in religion, could eventually create awareness in religion. It was agreed by Nurhasikin Lateh, student from class 6 and Mukminah Baso, students from the class 5 based on their experiences.

The power strategy with reward-punishment approach is important to be done because the students still need the direction for what is allowed or not allowed to be done. Moral problems seen in black and white terms, may or may not. The external authority determines what is good and bad. Moreover, the punishment which exists in Bakong Pittaya School is the physical punishment. For those who were not obey in doing the daily morning and afternoon ceremony, qiroati, midday and Friday prayer congregation, Khatm Al Qur'an, read Al Qur'an one month before examination, and 
wear the covered uniform and Melayu uniform, will be stricken with rattan or pinched, even their name will be written and report to the parents.

Meanwhile, besides the power strategy, the habituation and exemplary approach which include in the persuasive strategy also important to be done. The religious culture which has been reached need this approach to make it always run well, civilize, and maintain. The students still need the habituation and good example in running the religious culture over and over.

So, the prathom level of Bakong Pittaya School Pattani, Thailand use the instructive sequential strategy in reaching religious culture and the power and persuasive strategy in civilizing religious culture itself. The using of the strategies both of persuasive strategy and power strategy, is effective enough. The elementary students need the direction, good example, and people's power in the same time. The using people power without any supporting environment will not run well, and using the persuasive strategy without any rules from principal will not run orderly. So, this school needs both. Besides creating the proper environment, the school also need to regulate.

Moreover, religious culture which was implemented with those strategies hopefully will increase the religious sense and awareness upon the school's citizen. The Islamic values and teachings will embedded in the students' self and they can be able to be the good Muslims and proud of it even when they are in the middle of majoritarian environment and authority. As the effort to maintain Islamic identity, the school with the religious culture on it, tried to establish the spirit of Ibadah and defend Islamic religion to be exist in Thailand.

\section{CONCLUSIONS AND SUGGESTIONS}

The implementation of religious culture is about the reaching and civilizing religious culture itself. In reaching religious culture, the prathom level in Bakong Pittaya School Pattani, Thailand uses the Instructive Sequential Strategy through creating religious atmosphere, values internalization, good example, habituation, and the religious culture is reached. The religious culture itself still need the efforts to always maintained and civilized. Meanwhile, in civilizing religious culture, this school use the power strategy with reward-punishment approach, and persuasive strategy with habituation and exemplary approach. 
Moreover, there are 14 kind of religious culture form in the prathom level of Bakong Pittaya School Pattani, Thailand, i.e: (1) daily morning and afternoon ceremony, (2) commemoration of momentous days of Islam, (3) qiroati, (4) midday prayer congregation, (5) wearing the covered uniform and Melayu uniform, (6) read Al Qur'an 1 month before examination, (7) บำพ็ญ บระโยชน์= bam pen bpra yoht (useful activity), (8) religion quotes, (9) extracurricular activity (nasyid), (10) Friday prayer congregation, (11) khatm Al Qur' an for the 6th grade, (12) give Ramadhan foods, and (13) festivity before the examination, and (14) forgive each other after the examination. 


\section{REFERENCES}

https://en.wikipedia.org/wiki/Thailand

Al-Nahlawi, A. (1983). Ushul al-Tarbiyah al-Islamiyah wa Asalibiha fi al-Bait wa alMadrasah wa al-Mujtama'. Damsik: Dar al-Fikr.

Alim, M. (2008). Pendidikan Agama Islam: Upaya Pembentukan Pemikiran dan Kepribadian Muslim. Bandung: PT. Remaja Rosdakarya.

Alwasilah, C. (2014). Islam, Culture and Education. Bandung: PT Remaja Rosdakarya.

Arikunto, S. (2002). Prosedur Penelitian Suatu Pendekatan Praktik. Jakarta: PT Rineka Cipta.

Attaran, M. (2015). Moral Education, Habituation, and Divine Assistance in View of Ghazali. Journal of Research on Christian Education University of Malaya, 06 April 2015, Printed by Routledge.

Creswell, J. W. (2010). Research Design: Pendekatan Kualitatif, Kuantitatif, dan Mixed, trans. Achmad Fawaid. Yogyakarta: Pustaka Pelajar.

Ekwutosi, O., \& Moses, O. (2013). Internalization of Organizational Culture: A Theoretical Perspective. International Journal of Business Tourism and Applied Sciences, 1(2).

Fathurrohman, M. (2015). Budaya Religius dalam Peningkatan Mutu Pendidikan. Yogyakarta: Kalimedia.

Hasanah, U. (2014). Peran Guru Pendidikan Agama Islam Dalam Mewujudkan Budaya Religius Di Unit Pelaksana Teknis Dinas Sekolah Menengah Kejuruan Negeri 02 Boyolangu Tulungagung. Institut Agama Islam Negeri (IAIN) Tulungagung.

Khadziq. (2009). Islam dan Budaya Lokal: Belajar Memahami Realitas Agama dalam Masyarakat. Yogyakarta: Teras.

Majid, A., \& Andayani, D. (2012). Pendidikan Karakter Perspektif Islam. Bandung: PT Remaja Rosdakary.

Muhaimin. (2006). Nuansa Baru Pendidikan Islam. Jakarta: Rajawali Press.

Mulatsih. (2013). Implementasi "Religious Culture" Dalam Pendidikan Agama Islam (Studi Kasus Di Smk N 1 Wonosari, Gunungkidul). UIN Sunan Kalijaga.

Peterson, K. D., \& Deal, T. E. (2009). The Shaping School Culture Fieldbook; Second Edition. San Fransisco: Jossey-Bass.

Peterson, R., \& Wood., P. W. (2015). Sustainability: Higher Education's New Fundamentalism. New York: NAS.

Rahmahwati, I. (2015). Kontribusi Budaya Beragama dalam Pembelajaran PAI di SMK Triguna Utama. UIN Syarif Hidayatullah Jakarta. 
Rugg, G., \& Petre, M. (2007). A Gentle Guide to Research Methods. New York: Open University Press.

Sahlan, A. (2010). Mewujudkan Budaya Religius di Sekolah: Upaya Mengembangkan PAI dari Teori ke Aksi. Malang: UIN Maliki Press.

Sarkar, D. (2014). Religious Minority, Education and Separatism in South Thailand. Paper Presented at the 12th International Conference on Thai Studies at April 2224, 2014, Sydney: University of Sydney.

Sugiyono. (2016). Metode Penelitian Pendidikan (Pendekatan Kuantitatif, Kualitatif, dan $R \& D)$. Bandung: Alfabeta.

Tafsir, A. (1996). Pendidikan Agama dalam Keluarga. Bandung: PT. Remaja Rosdakarya.

Tafsir, A. (2004). Metodologi Pengajaran Agama Islam. Bandung: PT. Remaja Rosdakarya.

Ulwan, A. N. (1992). Pendidikan Anak Menurut Islam. Bandung: PT Remaja Rosdakarya.

Winasih, T. (2013). Peranan Budaya Sekolah Dalam Menumbuhkan Prestasi Belajar Pendidikan Agama Islam Di SD Dayakan II Dadapayu Semanu Kabupaten Gunungkidul Tahun Pelajaran 2010/2011. FAI (Pendidikan Agama Islam), 8(9).

Yusuf, I. (1999). Aspects of Islam in Thailand Today. ISIM Newsletter, Vol. 3, No. 99 Regional Issues, 3(99). 